\title{
STUDI POTENSI ENERGI TERBARUKAN DI KAWASAN TIMUR INDONESIA BERBASIS ANALISIS RETScreen INTERNATIONAL
}

\author{
THE STUDY OF RENEWABLE ENERGY POTENTIAL IN EASTERN \\ OF INDONESIA BASED ON RETScreen INTERNATIONAL ANALYSIS
}

\author{
Imran Amin ${ }^{1}$, Nadjamuddin Harun ${ }^{2}$, Ansar Suyuti ${ }^{3}$ \\ ${ }^{1}$ Teknik Energi Elektrik, Fakultas Teknik, Universitas Hasanuddin (aminimran7170@yahoo.com) \\ ${ }^{2}$ Teknik Energi Elektrik, Fakultas Teknik, Universitas Hasanuddin, \\ (Email:n harun@unhas.ac.id) \\ ${ }^{3}$ Teknik Energi Elektrik, Fakultas Teknik, Universitas Hasanuddin \\ (Email:suyuti128@cloud.com)
}

\author{
Alamat Korespondensi : \\ Imran Amin \\ Program Studi Teknik Elektro \\ Konsentrasi Teknik Energi Elektrik \\ Fakultas Teknik \\ Universitas Hasanuddin Makassar \\ Hp. 085255088388 \\ Email:aminimran7170@yahoo.com
}

\begin{abstract}
Abstrak - IMRAN AMIN. Studi Potensi Energi Terbarukan Di Kawasan Timur Indonesia Berbasis Analisis RETScreen International (dibimbing oleh Nadjamuddin Harun dan Ansar Suyuti). Potensi energi matahari (kWh/m2/d) 5,43 (Maluku), 4,97 (Papua) dan 5,66 (Sulawesi Barat) dan Potensi energi angin rata-rata 6,9 m/s perlu dikembangkan untuk meningkatkan rasio elektrifikasi. Penelitian ini bertujuan mendapatkan kelayakan pembangkit berdasarkan model energi, lingkungan dan ekonomi menggunakan software RETScreen International dan evaluasi kebijakan ketenagalistrikan. Simulasi PLTS 100 kWdengan modul Samsung LPC235SM dan PLTB 50.000 kWdengan50 unit turbin angin AAER 1000S 70, diperoleh energi PLTS (MWh) 126 (Maluku), 117,5 (Papua) dan 126,5 (Sulawesi Barat)dan energi PLTB (MWh) 92.650126 (Maluku), 91.269 (Papua) dan 91.937 (Sulawesi Barat). Pengurangan emisi GRK PLTS dan PLTB (t CO $/$ tahun) 92,2 dan 17.816 (Maluku), 85,9 dan 17.551 (Papua) dan 91,8 dan 17.679 (Sulawesi Barat). Hasil analisa finansial PLTS diperoleh IRR dan NPV 27,8\% dan \$269.489 (Maluku), 24,9\% dan \$230.709 (Papua) dan 27,6\% dan \$267.080 (Sulawesi Barat) sedangkan hasil analisa finansial PLTB diperoleh IRR dan NPV 13,1\% dan \$2.294.471(Maluku) 12,5\% dan \$ 1.021 .172 (Papua) dan 12,8\% dan \$1.637.070 (Sulawesi Barat). Kebijakan tarif dan subsidi untuk PLTS $\$ 30$ sen/kWh (\$300 per MWh) dan untuk PLTB Rp. 1250 per kWh ( $\$ 100$ per MWh) sudah memberikan hasil sebanding dengan biaya investasi dan operasional. Sehingga dapat disimpulkan bahwa PLTS dan PLTB pada provinsi Maluku, Papua dan Sulawesi Barat layak dan menguntungkan.
\end{abstract}

Kata kunci : PLTS, PLTB, Kebijakan Tariff, RETScreen International, emisi GRK, IRR, NPV 


\begin{abstract}
Abstarct - IMRAN AMIN. The Study of Renewable Energy Potential in Eastern of Indonesia Based on RETScreen International Analysis (supervised by Nadjamuddin Harun and Ansar Suyuti). The potency of solar energy $\left(\mathrm{kWh} / \mathrm{m}^{2} / \mathrm{d}\right)$ 5,43(Maluku), 4,97(Papua) and 5,66(West Sulawesi) and wind energy potential average 6,9 m/s should be developed to increase the electrification ratio, This study aims to get feasibility of plant based on energy models, environmental and economic use RETScreen International software and evaluation of electricity policy. $100 \mathrm{~kW}$ Solar Power Plant(SPP)simulationwith Samsung LPC235SM and WPP50,000 kW with 50 unit wind turbines AAER1000S70, gained SPPenergy (MWh) 126 (Maluku), 117,5 (Papua) and 126,5 (South West) and Wind Power Plant (WPP)energy (MWh) 92.650(Maluku), 91.269(Papua) and 91.937(West Sulawesi). SPPand WPPGHG emissions reduction (tCO2/year) are about 92,2 and 17.816 (Maluku), 85,9 and 17.551 (Papua) and 91,8 and 17.679 (West Sulawesi). SPP financial analysis results obtained IRR and NPV of 27,8\% and \$269,489 (Maluku), $24,9 \%$, and $\$ 230.709$ (Papua) and $27,6 \%$ and $\$ 267.080$ (West Sulawesi), while the results of the financial analysis WPP obtained IRR and NPV 13,1\% and \$2.294.471(Maluku) 12,5\% and \$1.021.172 (Papua) and 12,8\% and $\$ 1.637 .070$ (West Sulawesi). Feed-in Tariff policy and subsidies for SPP is $\$ 30$ cents $/ \mathrm{kWh}$ (\$300/MWh) and Rp.1.250/kWh (\$100/MWh) for WPPalready give good results when compared to the investment and operational costs. It concluded that SPP and WPP in this location are feasible and profitable.
\end{abstract}

Keywords: Solar Power Plant (SPP), Wind Power Plant (WPP), Feed-in Tariff, RETScreen International, GHG Emissions, IRR, NPV

\section{PENDAHULUAN}

Indonesia dengan letaknya di sepanjang equator dengan bentuk wilayah kepulauan dan memiliki garis pantai yang panjang memiliki potensi energi matahari $(\mathrm{kWh} / \mathrm{m} 2 / \mathrm{d}) \quad 5,43$ (Maluku), 4,97 (Papua) dan 5,66 (Sulawesi Barat) dan Potensi energi angin (pada ketinggian $20 \mathrm{~m}$ ) rata-rata $6,9 \mathrm{~m} / \mathrm{s}$ yang sangat layak untuk pengembangan pembangkit listrik tenaga surya dan pengambangan pembangkit listrik tenaga angin. Khususnya di kawasan timur Indonesia yang masih rendah rasio elektrifikasinya disebabkan oleh kondisi geografis dimana ketersediaan pembangkit jauh dari pusat beban, banyaknya pelanggan yang tersebar di pada daerah terpencil, terjauh pada pulau-pulau kecil dan terluar seperti di perbatasan sehingga pemanfaatan potensi energi matahari ataupun energi angin menjadi pertimbangan utama untuk meningkatkan rasio elektrifikasi di kawasan
Indonesia Timur (Manjang, S. dan I. Kitta ,2011).

Energi surya merupakan salah satu sumber energi terbarukan yang dimanfaatkan melalui dua macam teknologi yaitu teknologi fotovoltaik (PV) dan teknologi fototermik (surya termal). Teknologi PV mengkonversi langsung cahaya matahari menjadi listrik melalui perangkat semikonduktor yang disebut sel surya, sedangkan teknologi surya termal memanfaatkan panas dari radiasi matahari dengan menggunakan alat pengumpul panas atau yang biasa disebut kolektor surya. Teknologi PV dimanfaatkan untuk pembangkit listrik tenaga surya (PLTS) berupa sistem terpusat (centralized), sistem tersebar (stand alone) dan system hibrida (hybrid system). Centralized PV sistem adalah pembangkit listrik tenaga surya (PLTS) yang mensuplai listrik secara terpusat untuk berbagai lokasi/ beban yang bersifat on grid maupun off grid sedangkan sistem stand 
alone hanya mensuplai listrik khusus untuk kebutuhan beban yang tersebar di masingmasing lokasi dan bersifat off grid. Pada sistem hybrid, PLTS digunakan bersama-sama dengan sistem pembangkit lainnya dalam mensuplai listrik. Komponen sistem umumnya terdiri dari rangkaian sel surya yang membentuk modul surya ( $P V$ Panel) dan beberapa komponen pendukung seperti baterai, inverter, sistem kontrol dan lain-lain yang disebut juga sebagai balance of system / BOS. Aplikasi teknologi PV antara lain:PLTS pedesaan / perkotaan (on grid / offgrid), Solar Home System (SHS), solarstreet lighting, solar pumping, BST solar,solar refrigerator(Nafeh E.-S. A.,2009;Ahammed, F. and A. Azeem, 2009;Patricia H. J., 2012; Boedoyo, M. S., 2013).

Energi angin adalah sumber energi terbarukan yang dapat diubah menjadi energi mekanis dan listrik melalui sistem konversi dengan merubah energi kinetik yang ditampilkan dalam gerakan angin menjadi energi mekanis untuk mengoperasikan perlengkapan mekanis seperti pompa, kincir, dan lain-lain.Energi mekanis kemudian digunakan untuk memutar rotor dalam generator untuk menghasilkan listrik. Konversi keenergi mekanis disebut sistem konversi energi angin mekanis atau kincir angin, dan konversi ke listrik dilakukan dalam sebuah sistem konversi energi angin elektrik,yang lebih dikenal sebagai turbin angina (Tim Contaned Energi Indonesia, 2010 dan Sitompul, R.,2011). Penggunaan energi angin di lokasi yang dipilih membutuhkan data/informasi potensi (pasokan) angin aktual dan permintaan energi pada lokasi itu.Nasa Surface Meteorology And Solar Energy menyediakan data iklim yang dapat diakses melalui software RETScreen International untuk studi kelayakan dan evaluasi sistem.

RETScreen International adalah sebuah software yang digunakan untuk memfasilitasi studi pra-kelayakan dan studi kelayakan proyekproyek energi bersih. Dengan menerapkan lima langkah analisa proyek sesuai standar internasional, RETScreen International dapat membantu para stakeholders (terutama calon investor) untuk membuat keputusan-keputusan penting menjelang implementasi proyek. RETScreen yang didesain oleh RETSCreen International Canada, menyediakan fasilitas studi kelayakan untuk berbagai teknologi energi bersih, yaitu: energi angin, energi air skala kecil, energi surya, cogeneration (gabungan listrik dan panas), energi biomassa, pemanas udara tenaga surya, pemanas air tenaga surya, sistem pengendalian temperatur gedung pasif, dan pemompa panas dari sumber bawah tanah (panas bumi). Output yang dihasilkan RETScreen International meliputi kapasitas energi, estimasi pengurangan emisi gas rumah kaca,analisa finansial, analisa sensitifitas dan analisa resiko (Suyuti, A. dan Syafaruddin, 2012;Kaltschmitt, M., et al., 2007 dan Nainggolan, H. P.,2006)

Penelitian tentang Energi terbarukan antara lain oleh Muhammad Amin (2009) meneliti tentang pengembangan energi matahari 
dan energi angin dengan sistem hybrid denganmembuat design kriteria pada pembuatan prototype pembangkit listrik tenaga angin dan matahari sistem hybrid dengan method SURFER. Sedangkan Irwan Raharjo dan Ira Fitriana (2009) meneliti potensi PLTS dengan metode MARKAL untuk menganalisis optimasi alternatif pembangkit listrik dengan mempertimbangkan biaya terendah untuk pemilihan sumber energi dan teknologi pembangkit listrik dan dampak penggunaan energi terhadap lingkungan.sedangkan Eka Irawan (2010) menganalisis Energi Indonesia Dengan menggunakan Aplikasi LEAP dengan menganalisis energi Indonesia dari tahun 2010 sampai dengan 2030, konsumsi energi di hitung dari empat sektor yaitu ; rumah tangga, industri, jasa, dan transportasi. Penelitian lain dilakukan oleh Dewi Purnama Sari, Refdinal Nazir (2012) untuk menilai optimasi Sistem Pembangkit Listrik Tenaga Hybrid Diesel Generator Photovoltaic Array Menggunakan Homer, dan Firdaus Riyanda (2009) meneliti Pembangunan Pembangkit Listrik Energi Terbarukan PLTP 30 MW Untuk memenuhi Kebutuhan Listrik Di Pulau Sumbawa Nusa Tenggara Barat. Sedangkan Salama Manjang, Ikhlas Kitta (2011) mengevaluasi dan memetakan optimalisasi pemanfaatan potensi sumber energi terbarukan untuk pengembangan pembangkit tenaga listrik pada daerah yang terisolir dari listrik dengan metode LEAP (Longrange Energy Alternatives Planning), kemudian menganalisis optimalisasi dan ekonomis teknologi dengan konsep pembiayaan melalui investasi.

Penelitian ini bertujuan untuk mendapatkan kelayakan pembangkit berdasarkan model energi, lingkungan dan ekonomi dengan menggunakan software RETScreen International. Dan evaluasi kebijakan regulasi ketenagalistrikan di Indonesia (Road Map Energi Indonesia,2013; ESDM,2016).

\section{BAHAN DAN METODE Lokasi dan Waktu Penelitian}

Penelitian ini dilaksanakan di Kampus Universitas Hasanuddin Makassar, jalan Perintis Kemerdekaan KM 10, waktu pelaksanaan penelitian dan penulisan berlangsung bulan April 2016 sampai dengan Juli 2016

\section{Sumber data}

Data yang dibutuhkan dalam penelitian ini yaitu data iklim yang diperoleh dari RETScreen International. Data ini mengacu kepada hasil pengukuran satelit NASA di Amerika Serikat. Software ini sendiri dapat menampilkan data iklim pertahun pada beberapa tempat di seluruh dunia. Data iklim yang dimaksud adalah temperatur udara, kelembaban relatif, intensitas solar radiasi perhari, tekanan udara, kecepatan angin, temperature bumi dan sebagainya, dan data harga product dan data manufaktur energi photovoltaicdan manufaktur 
energi angin dari program RETScreen International.

Sumber data lainnya adalah ketentuan tarif (Feed-in Tariff) untuk PLTS dan PLTB, data perencanaan ketenagalistrikan yang berasal data dokumen RUPTL 2016 - 2025 (ESDM, 2016) berupa perencanaan kebutuhan listrik dan perencanaan pembangunan PLTS dan PLTB pada Provinsi Sulawesi Barat, Provinsi Maluku dan Provinsi Papua.

\section{Rancangan penelitian}

Penelitian dimulai dengan metode dokumentasi. Metode ini digunakan untuk memperoleh data-data yang spesifik dan akurat tentang intensitas cahaya, angin, suhu udara, kelembaban relatif, lokasi data iklim dan proyek yang bersumber dari software RETScreen International. Metode dokumentasi juga digunakan untuk mengumpulkan data-data pendukung berupa ketentuan tarif listrik, kebijakan subsidi, dan perencanaan kebutuhan listrik serta perencanaan pembangunan pembangkit listrik pada lokasi yang diteliti. Selanjutnya melakukan simulasi / menghitung berdasarkan data manufaktur energi terbarukan dengan softwareRET Screen International. Setelah selesai, langkah selanjutnya menganalisis output dari perhitungan RETScreen International ini berupa besar energi yang diekspor kejaringan, total pendapatan pertahun, dan menganalisis kelayakan finansial dari masing-masing model energi terbarukan.

Tahapan analisis selanjutnya dilakukan untuk pengambilan keputusan jenis energi yang potensial untuk dikembangkan yaitu dengan melakukan evaluasi kelayakan berdasarkan aspek teknologi berupa pertimbangan model energi yang layak dan menguntungkan, aspek lingkungan berupa penilaian tingkat pengurangan emisi gas rumah kaca (GRK) dan aspek ekonomi dengan menilai persentase IRR dan NPV dari perhitungan RETScreen International.Tahapan selanjutnya dilakukan analisis regulasi ketenagalistrikan yaitu dengan membuat perhitungan berdasarkan perencanaan kelistrikan dalam RUPTL 2016 - 2025 danmembuat skenario penambahan pembangkit PLTS dan PLTB serta menghitung pengurangan emisi GHG yang dihasilkan juga kontribusinya terhadap perencanaan pembangkit 2016 - 2025 menggunakan analisis regresi berganda.

\section{Model Analisis data}

Metode yang digunakan dalam analisis data dalam penelitian ini adalah analisis model energi, analisis keuangan, analisis emisi GHG, dan analisis kelayakan dengan software RETScreen International dan analisis statistik dengan software SPSS (Tsoutsos, T., et al.,2009; Wang, J.-J., et al.,2009; Suyuti, A. dan Syafaruddin, 2012).

\section{HASIL PENELITIAN}


Simulasi dengan model RETScreen International untuk PLTSmenggunakan 426 unit modul Mono-Si -LPC235SM faktor kapasitas $15 \%$, dimensi $1,6 \times 0,9 \mathrm{~m}^{2}$ dan intensitas radiasi $800 \mathrm{~W} / \mathrm{m}^{2}-1000 \mathrm{~W} / \mathrm{m}^{2}$ atau $4 \mathrm{kWh} / \mathrm{m} 2 / \mathrm{d}-5$ $\mathrm{kWh} / \mathrm{m} 2 / \mathrm{d}$ untukkapasitas daya $100 \mathrm{~kW}$ pada lokasi Provinsi Maluku, Papua dan Sulawesi Barat menghasilkan energi yang diekspor ke jaringan PLN sebesar 126,0 MWh (di Maluku), 117,5 MWh (di Papua) dan 126,5 MWh (di Sulawesi Barat) yang dihasilkan berdasarkan karakteristik manufaktur dan karakteristik iklim yaitu intensitas radiasi matahari pertahun sebesar $5,43 \mathrm{kWh} / \mathrm{m} 2 / \mathrm{d}$ (di Maluku), 4,97 kWh/m2/d (di Papua) dan 5,66kWh/m2/d (di Sulawesi Barat) serta diperoleh pengurangan emisi GHG (tCO2/tahun) 92,2 (di Maluku) dan 85,9 (di Papua) dan 91,8 (di Sulawesi Barat) dengan biaya modul $\$ 3000 / \mathrm{kW}$. (Tabel 1)

Simulasi dengan model RETScreen International untuk PLTBmenggunakan 50 unit turbin angin AAER 1000 dengan ketinggian tower 70 meter sehingga diperoleh kecepatan angin rata-rata $6,9 \mathrm{~m} / \mathrm{s}$ maka diperoleh energi listrik (MWh) 92.650 (di Maluku), 91.269 (di Papua) dan 91.937 (di Sulawesi Barat ) dan pengurangan emisi GHG (tCO2/tahun) 17.816 (di Maluku) dan 17.561 (di Papua) dan 17.679 (di Sulawesi Barat) dengan total biaya $\$ 1.800$ per $\mathrm{kW}$, dimana $\$ 700$ per $\mathrm{kW}$ disubsidi oleh pemerintah dan $\$ 1.100$ per $\mathrm{kW}$ ditanggung investor. (tabel 2)
Hasil simulasi analisa finansial pada proyek pembangkit listrik PLTS di kota Ambon, listrik yang diekspor ke jaringan $126 \mathrm{MWh}$, harga ekspor listrik $\$ / M W h$ 420, pendapatan tahunan $\$ 52.922$, biaya tahunan $\$ 33.108$, dan IRR 27,8\% sedangkan NPV \$ 269.489 untuk tingkat bunga 7\%. Hasil simulasi analisa finansial pada proyek pembangkit listrik PLTS di kota Jayapura, listrik yang diekspor ke jaringan $117 \mathrm{MWh}$, harga ekspor listrik \$/MWh 420, pendapatan tahunan $\$ 49,338$, biaya tahunan \$33.108, dan IRR 24,9\%. sedangkan NPV \$ 230.709 untuk tingkat bunga 7\%.Hasil simulasi analisa finansial pada proyek pembangkit listrik PLTS di kota Majene, listrik yang diekspor ke jaringan $125 \mathrm{MWh}$, harga ekspor listrik \$/MWh 420, pendapatan tahunan \$ 52.700, biaya tahunan $\$ 33.108$, dan IRR 27,6\%. sedangkan NPV \$ 267.080 untuk tingkat bunga 7\%.(Tabel 3)

Hasil simulasi analisa finansial pada proyek pembangkit listrik PLTB di kota Ambon, listrik yang diekspor ke jaringan 92.650 MWh, harga ekspor listrik \$ /100MWh, pendapatan tahunan $\$ 52.700$, biaya tahunan $\$ 8.244 .523$, dan IRR 13,1\%. sedangkan NPV \$ 2.294.471 untuk tingkat bunga 7\%.Hasil simulasi analisa finansial pada proyek pembangkit listrik di kota Jayapura, listrik yang diekspor ke jaringan 91.269 MWh, harga ekspor listrik \$ /100MWh, pendapatan tahunan $\$ 9.126 .870$, biaya tahunan \$8.244.523, dan IRR 12,5\%. sedangkan NPV \$ 1.021.172 untuk tingkat bunga 7\%.Hasil simulasi analisa finansial pada proyek 
pembangkit listrik di kota Majene, listrik yang diekspor ke jaringan 91.937 MWh, harga ekspor listrik \$ /100MWh, pendapatan tahunan \$ 9.193.702, biaya tahunan $\$ 8.244 .523$, dan IRR 12,8\%. sedangkan NPV \$ 1.637 .070 untuk tingkat bunga $7 \%$. (tabel 4 )

Kelayakan pembangkit PLTS dan PLTB berkaitan dengan sejumlah aspek dengan beberapa kriteria yang dapat dikategorikan sebagai kriteria pendukung dan kriteria yang perlu dioptimalkan yaitu : 1. kriteria pendukung ( cukup intensitas radiasi matahari, cukup kecepatan angin, hemat bahan bakar, mudah diinstalasikan, mudah dipasang pada daerah terpencil, ramah lingkungan, membuka peluang dan lapangan kerja, kebijakan tarif, insentif dan subsidi). 2. Kriteria yang perlu dioptimalkan ( pengembangan industri dalam negeri untuk suku cadang, SDM terampil untuk operator dan maintenance dan dukungan riset dan pengembangan )

Kebutuhan listrik tahun 2016 provinsi Maluku $121 \mathrm{MWh}$ dengan total kapasitas pembangkit 151,4 MWh dan kebutuhan listrik di hingga tahun 2025 mencapai 285 MW dengan total kapasitas pembangkit direncanakan mencapai 686,8 MW terdiri dari 151,4 PLTD , 295 PLTMG, 20 PLTP, 38,4 PLTM, 130 PLTU, 16 PLTA, 6 PLTBM, 10 PLTS dan 20 PLTB. sedangkan kebutuhan listrik tahun 2016 provinsi Papua 140 MWh dengan total kapasitas pembangkit 264,8 MWh dan kebutuhan listrik hingga tahun 2025 mencapai 308 MW dengan total kapasitas pembangkit direncanakan mencapai 683 terdiri dari 225,6 PLTD, 7,3 PLTD/PLTM, 13,9 PLTD/PLTS, 220 PLTMG, 130 PLTU, 16 PLTA, 6 PLTBM, 10 PLTS dan 20 PLTB. Dan kebutuhan listrik di provinsi Sulawesi Barat tahun 2016 mencapai $61 \mathrm{MWh}$ dengan total kapasitas pembangkit 8,41 MWh dan kebutuhan listrik mencapai 134 MW pada tahun 2025 dengan total kapasitas pembangkit direncanakan mencapai 609,41 terdiri dari 50 PLTU, 5 PLTBM, 546 PLTA, dan 8,41 PLTD.(tabel 5)

\section{PEMBAHASAN}

Dalam simulasi dengan data sebagaimana pada tabel 1 di atas digunakan produk manufaktur samsung Mono-Si LPC235SM dengan kapasitas daya perunit 235 Watt sehingga untuk mendapatkan kapasitas PLTS $100 \mathrm{~kW}$ diperlukan 426 unit modul Mono-Si -LPC235SM. Dengan luas modul 1,6 x $0,9 \mathrm{~m}^{2}$ perunit maka 426 unit modul memerlukan luas area minimal $625 \mathrm{~m}^{2}$ ( $25 \mathrm{~m} \mathrm{x}$ $25 \mathrm{~m}$ ), dalam simulasi ini luas area yang digunakan seluas $855 \mathrm{~m}^{2}$. Modul ini beroperasi pada intensitas radiasi matahari $800 \mathrm{~W} / \mathrm{m}^{2}$ $1000 \mathrm{~W} / \mathrm{m}^{2}$ atau $4 \mathrm{kWh} / \mathrm{m}^{2} / \mathrm{d}-5 \mathrm{kWh} / \mathrm{m} 2 / \mathrm{d}$. Dengan intensitas radiasi $\left(\mathrm{kWh} / \mathrm{m}^{2} / \mathrm{d}\right) \quad 5,43$ (Maluku), 4,97 (Papua) dan 5,66 (Sulawesi Barat) maka modul ini dapat bekerja maksimal pada lokasi ini. Tinggi rendahnya tingkat intensitas radiasi yang diterima pada modul akan mempengaruhi besarnya energi listrik yang 
dihasilkannya sehingga terdapat variasi besar energi pada ketiga lokasi yang disimulasikan. Variasi besar energi yang dihasilkan oleh PLTS mempengaruhi tingkat pengurangan emisi GHG yang disebabkan oleh PLTS, semakin besar energi listrik yang dihasilkan semakin tinggi tingkat pengurangan emisi GHG dalam simulasi ini.

Dalam simulasi dengan data sebagaimana pada tabel 2 di atas digunakan produk 50 unit turbin angin AAER 1000 dengan ketinggian tower 70 meter dengan kapasitas daya perunit 1000 Watt sehingga untuk mendapatkan kapasitas PLTS $50.000 \mathrm{~kW}$ diperlukan 50 unit turbin angin. turbin ini beroperasi pada kecepatan angin minimal $4 \mathrm{~m} / \mathrm{s}$, pada ketinggian 20 meter maka kecepatan angin rata-rata mencapai $6,9 \mathrm{~m} / \mathrm{s}$. Selain oleh karakteristik turbin angin, perubahan kecepatan angin akan mempengaruhi besar energi listrik yang dihasilkannya sehingga penempatan turbin pada lokasi dengan kecepatan angin yang sesuai adalah sangat penting untuk menjaga pasokan listrik yang dihasilkan tetap stabil.

Tabel 3 menunjukkan hasil analisis finansial pada simulasi PLTS pada lokasi yang dikaji. Besarnya harga ekspor listrik yang ditetapkan berkaitan dengan besarnya biaya investasi dan biaya operasional yang dikeluarkan oleh investor. Rendahnya harga ekspor listrik yang dikenakan oleh PLN yang tidak sebanding dengan biaya investasi dan operasional akan menyebabkan rendahnya minat investor untuk berinvestasi dalam pengembangan pembangkit PLTS walaupun potensi energi matahari sangat besar dan kemudahan instalasi dan mobilitas sistem ini sangat layak. Tingginya biaya investasi disebabkan karena konponen bahan baku yang masih didominasi oleh bahan impor. Diharapkan adanya pengembangan industri dalam negeri yang dapat mengatasi masalah ini. Pemerintah Indonesia sudah menetapkan kebijakan tarif ( feed in tariff) untuk energi terbarukan yang memperhitungkan tarif transfer listrik ke PLN yang sebanding dengan biaya investasi untuk PLTS ini. Untuk saat ini tarif transfer listrik (feed in tariff) ini adalah \$ 25 sen sampai \$ 30 sen per $\mathrm{kWh}$. Harga tertinggi \$ 30 sen per $\mathrm{kWh}$ diberikan apabila investor menggunakan 40\% komponen dalam negeri dalam pengembangan PLTS. Dalam perhitungan simulasi ini digunakan harga $\$ 420$ per MWh untuk penjualan listrik ke PLN. Dalam simulasi ini diperoleh persentase IRR adalah lebih dari tingkat bunga $7 \%$ yang ditetapkan yaitu 27,8 \% (Maluku), 24,9\% (Papua) dan 27,6 ( Sulawesi Barat) dan dengan perhitungan NPV pada tingkat bunga 7\% diperoleh nilai NPV \$ 269.489 (Maluku), \$230.709 (Papua) \$ 267.080 (Sulawesi Barat) sehingga proyek PLTS dalam simulasi ini layak yang menguntungkan.

Tabel 4 menunjukkan hasil analisis finansial pada simulasi PLTB pada lokasi yang diteliti. Harga ekspor listrik dalam simulasi ini ditetapkan \$ 100/MWh. Untuk harga ekspor listrik dari pembangkit PLTB di Indonesia pemerintah belum menetapkan tarif resmi yang 
sesuai, saat ini sedang diusulkan harga Rp. 1.250 per $\mathrm{kW}$ harga ini sebanding dengan harga \$ 100 per MWh pada kurs Rp. 12.500 per $\$ 1$. Jika harga ekspor listrik yang dikenakan oleh PLN yang tidak sebanding dengan biaya investasi dan operasional akan menyebabkan rendahnya minat investor untuk berinvestasi dalam pengembangan pembangkit PLTB. Tingginya biaya investasi disebabkan karena konponen bahan baku yang masih didominasi oleh bahan impor. Dalam simulasi ini diperoleh persentase IRR adalah lebih tinggi dari tingkat bunga $7 \%$ yang ditetapkan yaitu 13,1\% (Maluku), 12,5\% (Papua) dan 12,8 ( Sulawesi Barat ) dan dengan perhitungan NPV pada tingkat bunga 7\% diperoleh nilai NPV \$ 2.294.471 (Maluku), \$ 1.021.172 (Papua) \$ 1.637.070 (Sulawesi Barat) sehingga proyek PLTB dalam simulasi ini layak yang menguntungkan.

Berdasarkan tabel 5 kebutuhan listrik tahun 2016 diprediksi meningkat 100\% hingga tahun 2025. Berdasarkan prediksi ini maka perencanaan pembangunan pembangkit listrik dilakukan untuk mengantisipasi peningkatan ini. Perencanaan pembangkit listrik yang dilakukan pemerintah mencapai 686,8 MWh (Maluku), 683 MWh (Papua), dan 609,41 MWh (Sulawesi Barat) sudah mampu memenuhi kebutuhan listrik pada ketiga lokasi ini. Namun demikian belum semua area dapat tersentuh sarana kelistrikan yang bersumber dari PLN disebabkan kondisi lokasi pembangkit yang jauh dari pusat beban sehingga target rasio elektrifikasi dapat tidak terpenuhi jika tidak ditemukan solusi untuk mengantisipasi lokasi yang sulit dijangkau ini. Keungulan PLTS dan PLTB yang dapat ditempatkan secara tersendiri ( stand alone) maupun hibrid dan terkoneksi dengan grid PLN menjadi pilihan yang baik dengan potensi energi matahari dan energi angin yang melimpah khususnya di wilayah Indonesia Timur ini. Untuk wilayah yang sulit dijangkau dan memungkinkan pembangunan PLTS dan PLTB, pemerintah merencanakan 10 MW PLTS dan 20 MW PLTB di Maluku, 13,9 MW PLTS hybrid dengan PLTD, dan 20 MW PLTS di Papua, sedangkan di Sulawesi Barat tidak terdapat perencanaan PLTS ataupun PLTB padahal dari kajian dengan simulasi RETScreen International, potensi energi matahari sangat tinggi yaitu $5,66 \mathrm{kWh} / \mathrm{m} 2 / \mathrm{d}$.

\section{KESIMPULAN DAN SARAN}

\section{Kesimpulan}

1. Pemanfaatan energi surya dan energi angin di kawasan timur Indonesia masih terkendala dengan teknologi produksi yang mahal dengan biaya investasi awal yang tinggi sehingga pemanfaatannya belum secara maksimal dilakukan

2. Simulasi PLTS dengan modul PV Mono$\mathrm{Si}$-LPC235SM menggunakan model RETScreen International pada lokasi Provinsi Maluku, Papua dan Sulawesi Barat pada kapasitas PLTS $100 \mathrm{~kW}$ menghasilkan listrik (MWh) 126,006 (di Maluku), 117,471 (di Papua) dan 126,475 
(di Sulawesi Barat) serta diperoleh pengurangan emisi GHG (tCO2/tahun) 92,2 (di Maluku) dan 85,9 (di Papua) dan 91,8 (di Sulawesi Barat) dengan biaya modul \$3000/ kW. Sedangkan Simulasi PLTB dengan penggunaan 50 unit turbin angin AAER 1000 dengan ketinggian tower 70 meter diperoleh energi listrik (MWh) 92.650 (di Maluku), 91.269 (di Papua) dan 91.937 (di Sulawesi Barat ).

3. Dengan kemudahan instalasi dan kemampuannya menjangkau daerah terisolir, dan kemampuan mereduksi emisi gas GHG serta tidak terdapat dampak kebisingan dan pencemaran maka pembangkit ini ramah lingkungan. Serta secara ekonomis memiliki nilai IRR 27,8\% (di Maluku), 24,99\% ( di Papua ) dan 27,6 \%( di Sulawesi Barat) dengan NPV (\$) 269.489 (di Maluku), 230.709 ( di Papua ) dan 267.080 ( di Sulawesi Barat) pada tingkat bunga 7\% sehingga PLTS ini layak dan menguntungkan. Sedangkan untuk PLTB secara teknologi masih terkendala mahal dan kurang tersedianya suku cadang dan jasa perawatan sedangkan secara lingkungan walaupun dapat mereduksi emisi GHG tetapi juga memerlukan lahan yang luas dan strategis. walaupun secara ekonomis memiliki nilai IRR 13,1\% (di Maluku), 12,5 ( di Papua ) dan 12,8 ( di Sulawesi Barat) dengan NPV (\$) 2.294.471 (di Maluku), 1.021.172 ( di Papua ) dan
1.637.070 ( di Sulawesi Barat) pada tingkat bunga $7 \%$ sehingga PLTB ini layak dan menguntungkan

4. Walaupun potensi energi surya dan energi angin layak dikembangkan pada ketiga lokasi, pembangunan pembangkit yang direncanakan pemerintah hanya $10 \mathrm{MW}$ (PLTS) dan 20 MW (PLTB) di Maluku, 20 MW (PLTS) di Papua dan tidak terdapat perencanaan pembangunan pembangkit PLTS ataupun PLTB di Sulawesi Barat. Kebijakan tarif (Feed-in tariff) 25 sen / kW hingga 30 sen / kW untuk penjualan listrik PLTS ke PLN perlu disosialisasikan untuk menarik minat calon investor. Sedangkan kebijakan tarif untuk listrik PLTB yang belum ditetapkan perlu dikalkulasi secara cermat untuk mendapatkan harga yang layak untuk investasi PLTB. nilai $\$ 420$ per MWh ( \$ 25 sen / kWh) untuk PLTS dan $\$ 100$ per MWh (Rp. $1250 /$ kWh) dalam simulasi ini layak dan menguntungan.

\section{Saran}

1. Pemerintah perlu mempertegas dan mensosialisasikan kebijakan yang dapat mendorong investasi PLTS di indonesia seperti penyesuaian dalam kebijakan tarif transfer listrik ke PLN, kebijakan penggunaan komponen dalam negeri, dan kebijakan tentang prioritas pemanfaatan 
energi terbarukan untuk meningkatkan rasio elektrifikasi di Indonesia.

2. Perlunya meningkatkan dukungan terhadap pengembangan PLTS dan PLTB meliputi pengembangan industri dalam negeri untuk komponen teknologi PLTS dan PLTB, termasuk suku cadang, penyediaan SDM terampil untuk operasional dan perawatan, ketersediaan lahan dan dukungan riset dan pengembangan system yang sesuai.

3. Perlunya pemerintah secara kontinu melakukan evaluasi dan penyesuaian terhadap perencanaan energi yang sesuai dengan potensi lokal wilayah dan mengacu kepada pencapaian target minimal $23 \%$ bauran EBT hingga tahun 2025 dan minimal $31 \%$ bauran EBT hingga tahun 2050.

\section{UCAPAN TERIMA KASIH}

Penulis menyadari bahwa penyusunan penelitian ini banyak mengalami rintangan, tantangan dan hambatan, namun dengan bantuan dari berbagai pihak maka semua ini dapat diselesaikan dengan baik. Oleh karena itu, pada kesempatan ini penulis menyampaikan rasa terima kasih dan penghargaan yang setinggitingginya kepada Bapak Prof. Dr. H.Ir. Nadjamuddin Harun, dan Bapak Prof. Dr. Ir.H. Ansar Suyuti, MT. selaku pembimbing yang banyak memberi motivasi dan waktu luang untuk memberikan petunjuk dan bimbingan sehingga penyelesaian tesis ini dapat berlangsung dengan baik. Terima kasih juga saya sampaikan kepada bapak dan ibu dosen yang telah memberikan masukan dan bimbingan selama penulis menempuh perkuliahan.

\section{DAFTAR PUSTAKA}

Ahammed, F. and A. Azeem (2009). An economic analysis of solar PV micro-utility in rural areas of Bangladesh. Developments in Renewable Energy Technology (ICDRET), 2009 1st International Conference on the, IEEE.

Amin, M. (2009). Pengembangan Energi Matahari dan Angin Sistem Hibrid.

Boedoyo, M. S. (2013). Potensi dan Peranan PLTS Sebagai Energi Alternatif Masa Depan di Indonesia. Jurnal Sains dan Teknologi Indonesia

ESDM,(2016) RUPTL 2016 - 2025

Faisal Ahmmmed dan Abdullahil Azeem (2009), An Economic Analysis of Solar PV Micro-Utility in Rural Areas of Bangladesh

IRAWAN, E., et al. (2014). Analisis Energi Indonesia: Aplikasi LEAP, Universitas Gadjah Mada.

Kaltschmitt, M., et al. (2007). Renewable energy: technology, economics and environment, Springer Science \& Business Media.

Manjang, S. and I. Kitta (2011). "Pemetaan dan Optimalisasi Pemanfaatan Potensi Sumber Energi Terbarukan untuk Pengembangan Pembangkit Tenaga Listrik Pada Daerah yang Terisolir Dari Listrik PLN."

Nafeh E.-S. A. (2009), Design and Economic Analysis of a StandAlone PV System to Electrify a Remote Area Household in Egypt. The open renewable energy journal

Nainggolan, H. P. (2006). Studi Keekonomian Pembangkit Listrik Energi Terbarukan Terpadu Surya-Mikro Hidro.

Nasa Surface Meteorology And Solar Energy: RETScreen Data, diakses pada tanggal 24 Nopember 2012 (https://eosweb.larc.nasa.gov/sse/RETScreen/)

Patricia H. J. (2012). Analisis Keekonomian Kompleks Perumahan Berbasis Energi Sel Surya, UI, Jakarta.

Rahardjo, I. and I. Fitriana (2005). Analisis Potensi Pembangkit Listrik Tenaga Surya di Indonesia. Strategi Penyediaan Listrik Nasional Dalam Rangka Mengantisipasi Pemanfaatan PLTU Batubara Skala Kecil, PLTN, dan Energi Terbarukan, P3TKKE, BPPT, Januari.

RENDRA, M. and I. A. Budiman (2013). Pemodelan Perencanaan Energi di Indonesia, Universitas Gadjah Mada.

Riyanda, F. (2009). Studi Pembangunan Pembangkit Listrik Energi Terbarukan (PLTP) 30 MW Untuk memenuhi Kebutuhan Listrik Di Pulau Sumbawa Nusa Tenggara Barat.

Road Map Energi Indonesia (2013). Kementrian ESDM. Jakarta.

Sari, D. P. and R. Nazir (2015). Optimalisasi desain sistem pembangkit listrik tenaga hybrid diesel generatorphotovoltaic array menggunakan HOMER (studi kasus: Desa Sirilogui, Kabupaten Kepulauan Mentawai).Jurnal Nasional Teknik Elektro

Sitompul, R. (2011). Manual Pelatihan Teknologi Energi Terbarukan yang Tepat Untuk Aplikasi di Masyarakat Pedesaan. Jakarta: PNPM Support Facility (PSF): 45-75.

Suyuti, A.; Syafaruddin (2012).Studi Potensi Energi Matahari Berbasis Analisis RETScreen International di Sulawesi Selatan, Makassar.

Tim Contaned Energi Indonesia (2010), Modul Pelatihan Panduan Energi Terbarukan, Jakarta

Tsoutsos, T., et al. (2009). Sustainable energy planning by using multi-criteria analysis application in the island of Crete. Energy Policy37(5): 1587-1600.

Wang, J.-J., et al. (2009). Review on multi-criteria decision analysis aid in sustainable energy decision-making. 
Renewable and Sustainable Energy Reviews13(9): 2263-

2278. 


\section{LAMPIRAN}

Tabel 1.Model energi dengan PLTS yang disimulasikan dengan modelRETScreen International

\begin{tabular}{|c|c|c|c|}
\hline Uraian & Maluku & Papua & Sulawesi Barat \\
\hline Spesifikasi : & \multicolumn{3}{|c|}{$\begin{array}{l}\text { modul Samsung Mono-Si -LPC235SM faktor kapasitas } 15 \% \text {, dimensi 1,6 x 0,9 } \mathrm{m}^{2} \\
\text { dan intensitas radiasi } 800 \mathrm{~W} / \mathrm{m}^{2}-1000 \mathrm{~W} / \mathrm{m}^{2} \text { atau } 4 \mathrm{kWh} / \mathrm{m} 2 / \mathrm{d}-5 \mathrm{kWh} / \mathrm{m} 2 / \mathrm{d}\end{array}$} \\
\hline $\begin{array}{l}\text { Intensitas radiasi matahari } \\
(\mathrm{kWh} / \mathrm{m} 2 / \mathrm{d})\end{array}$ & 5,43 & 4,97 & 5,66 \\
\hline $\begin{array}{l}\text { Energi yang diekspor ke } \\
\text { jaringan } \mathrm{PLN}(\mathrm{MWh})\end{array}$ & 126,0 & 117,5 & 126,5 \\
\hline $\begin{array}{l}\text { Pengurangan emisi } \text { GHG } \\
\text { (tCO2/tahun) }\end{array}$ & 92,2 & 85,9 & 91,8 \\
\hline
\end{tabular}

Tabel 2.Model energi dengan PLTB yang disimulasikan dengan modelRETScreen International

\begin{tabular}{cccc}
\hline Uraian & Maluku & Papua & Sulawesi Barat \\
\hline Spesifikasi & 50 unit turbin angin AAER 1000 dengan ketinggian tower 70 meter \\
\hline $\begin{array}{c}\text { Kecepatan angin pada } \\
\text { ketinggian } 10 \text { m rata-rata } \\
(\mathrm{m} / \mathrm{s})\end{array}$ & 4,5 & 2,7 & 2,7 \\
\hline $\begin{array}{c}\text { Kecepatan angin pada } \\
\text { ketinggian } 20 \text { m rata-rata } \\
(\mathrm{m} / \mathrm{s})\end{array}$ & 6,9 & 6,9 & 6,9 \\
\hline $\begin{array}{c}\text { Energi yang diekspor ke } \\
\text { jaringan PLN(MWh) }\end{array}$ & 92.650 & 91.269 & 91.937 \\
\hline $\begin{array}{c}\text { Pengurangan emisi GHG } \\
\left(\mathrm{tCO}_{2} / \text { tahun }\right)\end{array}$ & 17.816 & 17.56 & 17.679 \\
\hline
\end{tabular}

Tabel 3.Analisis finansial dengan PLTS yang disimulasikan dengan modelRETScreen International

\begin{tabular}{cccc}
\hline Uraian & Maluku & Papua & Sulawesi Barat \\
\hline $\begin{array}{c}\text { Listrik yang diekspor ke } \\
\text { jaringan }(\mathrm{MWh})\end{array}$ & 126 & 117 & 125 \\
\hline harga ekspor listrik $(\$ / \mathrm{MWh})$ & 420 & 420 & 420 \\
\hline
\end{tabular}




\begin{tabular}{cccc}
\hline pendapatan tahunan (\$/tahun) & 52.922 & 49,338 & 52.700 \\
\hline biaya tahunan (\$) & 33.108 & 33.108 & 33.108 \\
\hline IRR (\%) & 27,8 & 24,9 & 27,6 \\
\hline $\begin{array}{c}\text { NPV pada tingkat bunga 7\% } \\
(\$)\end{array}$ & 269.489 & 230.709 & 267.080 \\
\hline
\end{tabular}

Tabel 4.Analisis finansial dengan PLTB yang disimulasikan dengan modelRETScreen International

\begin{tabular}{cccc}
\hline Uraian & Maluku & Papua & Sulawesi Barat \\
\hline $\begin{array}{c}\text { Listrik yang diekspor ke } \\
\text { jaringan }(\mathrm{MWh})\end{array}$ & 92.650 & 91.269 & 91.937 \\
\hline harga ekspor listrik (\$/MWh) & 100 & 100 & 100 \\
\hline pendapatan tahunan (\$/tahun) & 9.265 .037 & 9.126 .870 & 9.193 .702 \\
\hline biaya tahunan $(\$)$ & 8.244 .523 & 8.244 .523 & 8.244 .523 \\
\hline IRR (\%) & 13,1 & 12,5 & 12,8 \\
\hline $\begin{array}{c}\text { NPV pada tingkat bunga 7\% } \\
(\$)\end{array}$ & 2.294 .471 & 1.021 .172 & 1.637 .070 \\
\hline
\end{tabular}

Tabel 5.Kebutuhan listrik dan kapasitas pembangkit yang direncanakan oleh PLN 2016 - 2025

\begin{tabular}{|c|c|c|c|}
\hline Uraian & Maluku & Papua & Sulawesi Barat \\
\hline Kebutuhan listrik tahun 2016 & 121 & 140 & 61 \\
\hline $\begin{array}{c}\text { kapasitas pembangkit tahun } \\
2016\end{array}$ & 151,4 & 264,8 & 8,41 \\
\hline $\begin{array}{c}\text { Kebutuhan listrik sampai } \\
\text { tahun } 2025(\mathrm{MW})\end{array}$ & 285 & 308 & 134 \\
\hline $\begin{array}{c}\text { Total kapasitas pembangkit } \\
\text { sampai tahun } 2025(\mathrm{MW})\end{array}$ & 686,8 & 683 & 609,41 \\
\hline $\begin{array}{l}\text { Kapasitas dan jenis } \\
\text { pembangkit (MW) }\end{array}$ & $\begin{array}{c}151,4 \text { PLTD } \\
295 \text { PLTMG } \\
20 \text { PLTP } \\
38,4 \text { PLTM } \\
130 \text { PLTU }\end{array}$ & $\begin{array}{c}\text { 225,6 PLTD } \\
7,3 \text { PLTD/PLTM 13,9 } \\
\text { PLTD/PLTS } 220 \\
\text { PLTMG } \\
80 \text { PLTG/MG }\end{array}$ & $\begin{array}{l}50 \text { PLTU } \\
5 \text { PLTBM } \\
546 \text { PLTA } \\
8,41 \text { PLTD }\end{array}$ \\
\hline
\end{tabular}




\begin{tabular}{cc}
\hline 16 PLTA & 14,2 PLTM \\
6 PLTBM & 134 PLTU \\
10 PLTS & 70 PLTA \\
20 PLTB & 10 PLTBM \\
& 20 PLTS \\
& 1 PLTSa \\
\hline
\end{tabular}

